\title{
Risks and benefits of pasture irrigation using treated municipal effluent : a lysimeter case study, Canterbury, New Zealand
}

\author{
Maria Jesus Gutierrez-Gines ${ }^{1,2}$ (D) $\cdot$ Minakshi Mishra ${ }^{1} \cdot$ Cameron Mclntyre $^{1} \cdot$ Henry Wai Chau $^{1} \cdot$ Juergen Esperschuetz $^{1} \cdot$ \\ Roger McLenaghen ${ }^{1} \cdot$ Mike P. Bourke $^{3}$ - Brett H. Robinson ${ }^{1,4}$
}

Received: 19 September 2019 / Accepted: 15 January 2020 / Published online: 23 January 2020

(C) The Author(s) 2020

\begin{abstract}
Compared to discharge into waterways, land application of treated municipal effluent (TME) can reduce the need for both inorganic fertilizers and irrigation. However, TME irrigation may result in the accumulation of phosphorus $(\mathrm{P})$ or trace elements in soil, and increased salinity and sodicity, which could damage soil structure and reduce infiltration. TME irrigation can also result in groundwater contamination through nitrate leaching or surface water contamination through runoff. This study aimed to evaluate the effects of increasing TME irrigation rates on quantity and quality of leachate and pasture growth in a lysimeter experiment using a Fluvial Recent soil and a Fragic Pallic soil. Pasture growth in the lysimeters was up to 2.5-fold higher in the TME treatments compared to the non-irrigated treatments. There were no signs of toxicity or accumulation of $\mathrm{B}, \mathrm{Al}, \mathrm{Cd}, \mathrm{Cu}, \mathrm{Fe}, \mathrm{Mn}, \mathrm{As}$, and $\mathrm{Zn}$. TME significantly increased the concentration of $\mathrm{P}$ and $\mathrm{Na}$ in the pasture. Nitrogen leaching from the lysimeters was negligible $\left(<1 \mathrm{~kg} / \mathrm{ha}^{-1}\right.$ equiv. $)$ in all treatments, but mineral $\mathrm{N}$ accumulated in the soil profile of the highest application rate $(1672 \mathrm{~mm} / \mathrm{yr})$. Although more $\mathrm{P}$ was added than removed in pasture, the rate of accumulation indicated that over a 50-year period, $\mathrm{P}$ will still be within the current New Zealand thresholds for grazed pastures. Sodium accumulated in the soil columns in all the TME treatments. The rate of accumulation was not proportional to the TME application rate, indicating that Na was moving down through the soil profile and leaching. Results indicate a low to moderate risk of sodicity in soil or toxicity in plants caused by Na.
\end{abstract}

Keywords Treated municipal effluent reuse $\cdot$ Soil sodicity $\cdot$ Nitrogen leaching $\cdot$ Soil phosphorus $\cdot$ Wastewater

\section{Introduction}

Treated municipal effluent (TME) is a resource of water and plant nutrients, especially $\mathrm{N}$ and $\mathrm{P}$, and lower concentrations

Responsible author: Kitae Baek

Electronic supplementary material The online version of this article (https://doi.org/10.1007/s11356-020-07759-8) contains supplementary material, which is available to authorized users.

Maria Jesus Gutierrez-Gines

maria.gines@esr.cri.nz

1 Department of Soil and Physical Sciences, Lincoln University, Ellesmere Junction Road/Springs Road, Lincoln 7647, New Zealand

2 Institute of Environmental Science and Research Ltd, 27 Creyke Rd, Christchurch 8041, New Zealand

3 Christchurch City Council, 53 Hereford Street, Christchurch 8154, New Zealand

4 School of Physical and Chemical Sciences, University of Canterbury, 20 Kirkwood Ave, Christchurch 8041, New Zealand of K, Zn, B and S (Pedrero et al. 2010). As well as alleviating drought stress, irrigation with TME offsets the need for mineral fertilizers such as superphosphate, which, depending on their origin, may contain elevated concentrations of toxic cadmium, fluorine and uranium (Kim and Robinson 2015).

There are environmental benefits for using TME for irrigation if the alternative is discharge into waterways or the ocean, where the nutrients that TME contains can exacerbate eutrophication and/or toxic algal blooms (Sonune and Ghate 2004). Apart from taking up nutrients, plant roots can mitigate pathogens (Prosser et al. 2016) and break down or immobilize contaminants (Chaudhry et al. 2005) that would otherwise degrade water bodies. Protecting freshwater and reusing the resources of TME are major drivers for irrigation with TME (pasture, crops, forestry, urban gardens, among others), which can make up $>20 \%$ of the irrigation water in water-scarce regions around the world (Pedrero et al. 2010).

Irrigation with TME carries risks that need to be assessed and mitigated for a successful operation (Cameron et al. 1997). Increased salinity and/or sodicity in the soils (Pedrero et al. 2010; Qian and Mecham 2005; Zalacáin et al. 2019) can 
reduce soil fertility (Abrol et al. 1988) and damage soil structure through the dispersion of clays (Mojid and Wyseure 2013), thereby reducing the permeability of soils (Tanji 1997). TME may add trace elements to soils (Xu et al. 2010), which could enter the food chain (Asgari and Cornelis 2015; Pedrero et al. 2010).

Although the effect on groundwater is usually mentioned as a potential risk (Lal et al. 2015; Rattan et al. 2005), only Barton et al. (2005) and Sparling et al.( 2006) directly analysed $\mathrm{N}$ and $\mathrm{P}$ in the leachates resulting from soils irrigated with wastewater. They reported that the $\mathrm{N}$ and $\mathrm{P}$ leached was $3-5 \%$ and $<1 \%$ in pumice and allophanic soils, respectively, of the total $\mathrm{N}$ and $\mathrm{P}$ applied by TME irrigation. This percentage increased to $22 \%$ for $\mathrm{N}$ and $8-13 \%$ for $\mathrm{P}$ in gley and recent soils. These are two of the main concerns about water quality in New Zealand (MfE and MPI 2018).

The balance between the benefits of the water and nutrients supplied by TME irrigation, and the risks posed by potential contaminants or excess of certain elements, is dependent on the quality of the TME, as well as environmental conditions, including soil type, vegetation cover and climate (Pedrero et al. 2010). Although there is much research on the potential risks and benefits of irrigation with TME, there is a scarcity of experimental evidence that assess comprehensively the positive and negative effects of TME irrigation in all the affected compartments in the system: plant cover, soil and leachates.

To address this lack of experimental data, above all in quantity and quality of leaching, a lysimeter experiment was set up for assessing the benefits and risks of increasing irrigation rates of TME over two soil profiles with distinct pasture types. The objectives of this experiment were:

- To measure the pasture production and its quality in two soils types with TME irrigation

- To determine whether TME irrigation would cause excessive leaching of N, P, Na or trace elements

- To assess whether there would be an unacceptable accumulation of $\mathrm{P}, \mathrm{Na}$ or other elements in the soil

\section{Materials and methods}

\section{Field sites and soils and treated municipal effluent}

The two sites chosen for this experiment are currently under consideration for receiving TME from a wastewater treatment plant located in their proximity: a golf course and a grazed pasture. The Akaroa Golf Course is located in Duvauchelle, NZ (434ㄴ $53.06^{\prime \prime}$ S, $172^{\circ} 55^{\prime} 41.44^{\prime \prime}$ ) over a Fluvial Recent soil (Barry's soil, silt loam) (LandcareResearch 2018a), henceforth called Fluvial Recent soil site. The grazed pasture is located in Takamatua Peninsula $\left(43^{\circ} 47^{\prime} 33.11^{\prime \prime} \mathrm{S}, 172^{\circ} 57^{\prime}\right.$
16.96"E) over Fragic Pallic soil (Pawson silt loam) (LandcareResearch 2018a), referred to along the text as Fragic Pallic soil site. Before collecting the lysimeters, soil pits were opened to ascertain that they would have an adequate permeability to allow significant throughflow of water. Both soils are imperfectly drained (as indicated by mottling); however, there was no evidence of perched water or a fragipan. The particle size fractions for these soils were course sand 1.2 (s.d. 0.2 ) \%, fine sand 44.5 (s.d. 0.9) \%, silt 28.1 (s.d. 2.1) $\%$ and clay 24.0 (s.d. 2.2) \% (Anon, 1939).

The TME was sourced from Duvauchelle wastewater treatment plant $\left(43^{\circ} 45^{\prime} 07.16^{\prime \prime} \mathrm{S}, 172^{\circ} 56^{\prime} 22.81^{\prime \prime} \mathrm{E}\right)$. The wastewater received primary and secondary treatment within the plant followed by a UV disinfection. Table 1 shows the chemical characteristics of soils and TME.

\section{Lysimeter experiment set up and monitoring}

Lysimeters comprised intact soil cores ( $80 \mathrm{~cm}$ deep and $50 \mathrm{~cm}$ diameter) collected following the method of Cameron et al. (1992): they were excavated around a cylinder to minimize soil disturbance, with a 5-cm layer of gravel to allow for leaching. Molten petroleum jelly was injected around the edge of the lysimeter to eliminate bypass flow. Prior to the setup of the full lysimeter experiment, two intact lysimeters were collected from the Fluvial Recent soil site to test that the intact soil cores drained and therefore were suitable for the full experiment. These two lysimeters were taken to Lincoln University lysimeter facility $\left(43^{\circ} 38^{\prime} 53.54^{\prime \prime} \mathrm{S}, 172^{\circ} 28^{\prime} 7.69^{\prime \prime} \mathrm{E}\right)$ and irrigated with $2 \mathrm{~L}$ of water $(10 \mathrm{~mm})$ per day for 6 weeks until drainage was stabilized. After that, a further ten lysimeters were taken from the Fluvial Recent soil site and six were taken from the Fragic Pallic soil site. The original vegetation was kept in the lysimeters. The Fluvial Recent soil lysimeters were covered with a fescue/browntop (Festuca sp./Agrostis capillaris L.) mixture, which is a common golf course turf. These species grow densely but not very tall (compared with ryegrass), and they do not require intensive maintenance and fertilization. The Fragic Pallic soil lysimeters were dominated by perennial ryegrass (Lolium perenne L.), which is characterized by a high biomass production but needs maintenance and frequent fertilization compared with the golf course turf.

From 9 February to the 21 April 2015, the lysimeters were irrigated with $10 \mathrm{~mm} \mathrm{(2} \mathrm{L)} \mathrm{of} \mathrm{water} \mathrm{per} \mathrm{day,} \mathrm{to} \mathrm{provide} \mathrm{drain-}$ age a reasonable timeframe (about 2 weeks) without an unrealistically high water input. After 10 days, all the lysimeters started to drain, and after 6 weeks, similar volumes of leachate were obtained for all lysimeters; this irrigation was kept until 22 April, when TME application of the lysimeters began. TME was collected by the Christchurch City Council (CCC) from the Duvauchelle wastewater treatment plant and delivered to Lincoln University in a 1000-L tank. Samples of the stored TME were collected and analysed weekly. The tank 
Table 1 Characteristics of the treated municipal effluent (TME) used in the lysimeter experiment and the soil (A horizon) in the lysimeters

\begin{tabular}{|c|c|c|c|c|}
\hline Parameters & TME & TME guidelines & Fluvial Recent soil & Fragic Pallic soil \\
\hline $\mathrm{pH}$ & 7.5 & $6.5-8.4^{1}$ & 4.8 & 5.2 \\
\hline $\mathrm{EC}(\mu \mathrm{S} / \mathrm{cm})$ & $423(40)$ & $700^{1}$ & - & \\
\hline Total suspended solids & 32 & $450^{1}$ & - & - \\
\hline $\mathrm{NH}_{4}^{+}-\mathrm{N}$ & $0.49(0.15-0.80)^{*}$ & & $10.1(7.5)$ & $11(6.8)$ \\
\hline $\mathrm{NO}_{3}{ }^{-}-\mathrm{N}$ & $18(7.5)$ & $5^{1}-10^{2}$ & $4.4(1.1)$ & $17.1(13.2)$ \\
\hline $\mathrm{NO}_{2}{ }^{-} \mathrm{N}$ & $0.86(0.09)$ & & - & - \\
\hline Total C (\%) & - & & $4.4(0.6)$ & $5.4(0.3)$ \\
\hline Total N (\%) & $<0.025$ & & $0.38(0.05)$ & $0.48(0.03)$ \\
\hline $\mathrm{Al}$ & $0.43(0.11-1.7)^{*}$ & $5^{2}$ & $34,900(3700)$ & $32,700(1420)$ \\
\hline B & $0.10(0.04)$ & $0.7^{1}$ & & - \\
\hline $\mathrm{Ca}$ & $59(12)$ & & $5850(187)$ & $6770(393)$ \\
\hline $\mathrm{Cd}$ & $<0.001$ & $0.01^{2}$ & $<0.05$ & $<0.05$ \\
\hline $\mathrm{Cu}$ & $0.04(0.03)$ & $0.2^{2}$ & $5.1(1.4)$ & $7.7(0.2)$ \\
\hline $\mathrm{Fe}$ & $0.96(0.25-3.6)^{*}$ & $5^{2}$ & $16,800(4100)$ & $20,200(2850)$ \\
\hline $\mathrm{K}$ & $22(5.0)$ & & $4008(365)$ & $4490(346)$ \\
\hline $\mathrm{Mg}$ & $19(5.5)$ & & $3580(463)$ & $4250(76)$ \\
\hline $\mathrm{Mn}$ & $0.06(0.03)$ & $0.2^{2}$ & $496(50)$ & $624(9)$ \\
\hline $\mathrm{Na}$ & $95(21)$ & $69^{1}$ & $374(30)$ & $290(10)$ \\
\hline $\mathrm{P}$ & $11(5.0)$ & $5^{2}$ & $599(125)$ & $1050(30)$ \\
\hline S & $25(11)$ & & $430(5)$ & $490(21)$ \\
\hline $\mathrm{Zn}$ & $0.17(0.11)$ & $2^{2}$ & $62(7)$ & $68(3)$ \\
\hline SAR & 2.75 & & - & \\
\hline
\end{tabular}

*Geometric mean and standard deviation range

${ }^{1}$ FAO (Food and Agriculture Organization) guidelines for unrestricted reuse (FAO 2003)

${ }^{2}$ EPA (US Environmental Protection Agency) guidelines for agricultural reuse (EPA 2004)

Values in brackets represent the standard deviation of the mean. TME, $n=54$ except trace elements $n=14$. Concentrations of dissolved elements in TME are in $\mathrm{mg} / \mathrm{L}$, and the total elements in soils are expressed in $\mathrm{mg} / \mathrm{kg}$, unless otherwise indicated was refilled as needed. The chemical characteristics of the TME tank samples (Table 1) were similar to data provided by CCC from various times during the past 5 years (data not shown). Irrigation treatments were chosen to represent approximately half of the annual rainfall in the area (low TME application), same as the annual rainfall (medium TME application) and double the annual rainfall (high TME application). There were three replicates per treatment (Table 2).

TME was irrigated daily from the stored tank with a watering can for the period of 17.5 months (until 9 October 2016). The TME in the tank was homogenized every day before TME application with a hand stirrer. Drainage volumes were measured and collected weekly or more often following high rainfall events. Pasture was harvested periodically, typically every 3 weeks during the growing season or every 2 months over winter.

The experiment was conducted for 17.5 months, covering two wet seasons. At the end of the experiment, pasture was harvested for the final time, and the lysimeters were deconstructed. Soil samples were collected and analysed from $0-15,15-30,30-45$ to $45-60 \mathrm{~cm}$.

\section{Sample preparation and chemical analyses}

Samples of both the TME storage tank (duplicates) and the leachates were collected weekly. One sample per week from the TME storage tank was filtered through a $0.45-\mu \mathrm{m}$ syringe filter and frozen at $-20{ }^{\circ} \mathrm{C}$ until analysis. Other sample was frozen without filtering. All the leachate samples were filtered and stored at $-20{ }^{\circ} \mathrm{C}$ until analysis. $\mathrm{NO}_{3}{ }^{-} \mathrm{N}$ and $\mathrm{NH}_{4}{ }^{+}-\mathrm{N}$ were measured weekly in tank samples and leachates using a flow injection analyser (FIA FS3000 twin channel analyser, Alpkem, USA). $\mathrm{pH}$ was determined with a $\mathrm{pH}$ meter and conductivity meter (Mettler Toledo Seven Easy) and total C and $\mathrm{N}$ with a Vario-Max CN Elementar Analyser (Elementar ${ }^{\circledR}$, Germany). Every 2 months, acidified (using $1 \mathrm{~mL}$ of $6 \mathrm{M} \mathrm{HNO}_{3}$ into $30 \mathrm{~mL}$ ) subsamples of leachates and TME were analysed for $\mathrm{As}, \mathrm{B}, \mathrm{Ca}, \mathrm{Cd}, \mathrm{Cr}, \mathrm{Cu}, \mathrm{Fe}, \mathrm{K}$, $\mathrm{Mg}, \mathrm{Mn}, \mathrm{Mo}, \mathrm{Na}, \mathrm{P}, \mathrm{S}$ and $\mathrm{Zn}$ using inductively coupled plasma optical emission spectrometry (ICP-OES Varian 720 ES, USA). Unfiltered TME samples were also microwaved, digested (see method below) and analysed by ICP-OES. 
Table 2 Experimental design with two soil types and up to four TME irrigation rates and three replicate lysimeters per treatment

\begin{tabular}{lllll}
\hline Soil type / Irrigation & $0 \mathrm{~mm} / \mathrm{yr}$ & $446 \mathrm{~mm} / \mathrm{yr}$ & $836 \mathrm{~mm} / \mathrm{yr}$ & $1672 \mathrm{~mm} / \mathrm{yr}$ \\
\hline Fluvial Recent soil & X 3 & X 3 & X 3 & X 3 \\
Fragic Pallic soil & X 3 & - & X 3 & - \\
\hline
\end{tabular}

The fresh samples of soils were sieved $(<2 \mathrm{~mm})$, and $\mathrm{NO}_{3}{ }^{-}-\mathrm{N}$, and $\mathrm{NH}_{4}{ }^{+}-\mathrm{N}$ concentrations were determined on 2$\mathrm{M} \mathrm{KCl}$ extracts (Clough et al. 2001) and analysed with a flow injection analyser (FIA FS3000 twin channel analyser, Alpkem, USA). Sieved samples of soil were then dried at room temperature and analysed for $\mathrm{pH}$ and electrical conductivity in a 1:5 (w:v) soil-water ratio (Blakemore et al. 1987). Total $\mathrm{C}$ and $\mathrm{N}$ concentrations were determined using a VarioMax CN Elementar Analyser. Pseudo-total elements were extracted using the microwave CEM MARS Xpress acid digest technique (0.5-g substrate, $4.0-\mathrm{ml}$ trace element grade nitric acid (69\%) and $4.0 \mathrm{ml} \mathrm{30 \%} \mathrm{hydrogen} \mathrm{peroxide),} \mathrm{according} \mathrm{to}$ the equipment specifications. The Olsen $\mathrm{P}$ was extracted with $0.5-\mathrm{M} \mathrm{NaHCO}_{3}$ (Olsen et al. 1954). Exchangeable cations were extracted with $0.01-\mathrm{M} \mathrm{AgTU}^{+}$(silver thiourea) (Blakemore et al. 1987).

Samples of pasture were washed with tap water to remove soil and oven-dried at $65^{\circ} \mathrm{C}$ until constant weight was obtained. Dried samples were weighed and ground and passed through a $0.5-\mathrm{mm}$ stainless steel sieve.Total $\mathrm{C}$ and $\mathrm{N}$ concentrations were determined using a Vario-Max CN Elementar Analyser. Arsenic, $\mathrm{Ca}, \mathrm{Cd}, \mathrm{Cu}, \mathrm{K}, \mathrm{Mg}, \mathrm{Pb}, \mathrm{S}$ and $\mathrm{Zn}$ were analysed following acid digestion in a microwave (CEM MARS Xpress), using 0.3-g dried plant material ,2.0-ml trace element grade nitric acid (69\%) and $2.0 \mathrm{ml} \mathrm{30 \%} \mathrm{hydrogen}$ peroxide, according to the equipment specifications.

Analysis of elements in the extracts of soil and plants was determined by ICP-OES and expressed on a dry weight basis. The microwave extraction method was assessed using a reference soil (reference 981, sandy soil from the Netherlands) and a reference plant sample (reference 952, mixture of grasses from the Netherlands) from Wageningen Evaluating Programs for Analytical Laboratories (WEPAL, NL-6700 EC Wageningen, the Netherlands). Recoverable concentrations of the reference materials were within $93-110 \%$ of the certified values. For soils and plants, the detection limit (LD) was $0.05 \mathrm{mg} / \mathrm{kg}$ for most elements, and the quantification limit (LQ) was $0.1 \mathrm{mg} / \mathrm{kg}$. For solutions the LD and LQ were 50 times lower.

\section{Data analysis}

The sodium adsorption ratio (SAR) in soils and TME were calculated based on Ayers and Westcot (1985), using exchangeable $\mathrm{Ca}, \mathrm{Mg}$ and $\mathrm{Na}$ data in $\mathrm{meq} / \mathrm{L}$ or meq $/ \mathrm{kg}$.
Exchangeable sodium percentage (ESP) in soils was calculated using exchangeable $\mathrm{Na}, \mathrm{Ca}$ and $\mathrm{Mg}$ data in $\mathrm{cmol} / \mathrm{kg}$ (Abrol et al. 1988).

Data were analysed using Minitab® 17 (Minitab Inc., State College, Pennsylvania, USA) and Microsoft Excel 2013. The results from the two soils were analysed separately. For the results of the Fluvial Recent soil, the ANOVA with Tukey's post hoc test was used to assess the effects of different treatments. For the results of the Fragic Pallic soil, the t-test not assuming equal variances was used to assess the both treatments. The significance level for all statistical analyses was $P<0.05$.

\section{Calculations of phosphorus fluxes}

Data of $\mathrm{P}$ in TME, soil, leachate and biomass were used to calculate the $\mathrm{P}$ accumulation in the topsoil $(0-30 \mathrm{~cm})$ in a period of 50 years with 500-mm TME applied per year and three $\mathrm{P}$ concentrations in the TME. Calculations were done for the $0-30-\mathrm{cm}$ topsoil because it is a typical plough depth and is where the most root biomass is found. The parameters used in the model are shown in Table 3. The total concentration of $\mathrm{P}$ in the soil was calculated according to Eq. (1):

Total P $(\mathrm{mg} / \mathrm{kg})_{n}=P \operatorname{mass}(\mathrm{kg} P / h a)_{n} x$ 1000/Soil mass $(t / h a)$

where $P$ mass is the total amount of $\mathrm{P}$ in $\mathrm{kg} / \mathrm{ha}$ in the top $30 \mathrm{~cm}$ of soil in a certain year (n); and Soil mass is calculated in the $0-30 \mathrm{~cm}$ horizon with $1.4 \mathrm{t} / \mathrm{m}^{3}$ density.

For calculating the changes of $\mathrm{P}$ mass in the soil, the simulations assumed that all the $\mathrm{P}$ that is applied in the TME, and is not taken up by plants, or leached to deeper horizons, will accumulate in the soil, as exposed in Eq. (2). Loss by run off was not considered.

$$
\begin{aligned}
& P \operatorname{mass}(k g P / h a)_{n}=\left(P \operatorname{mass}_{n-1}+P \text { application }\right) \\
& -\left({\text { P } \text { leached }_{n-1}+\text { P }_{\text {uptake }}-1}\right)
\end{aligned}
$$

The initial $P$ mass (P mass $n$ n) was calculated based on the initial $P$ concentration in the soil (Tables 1 and 3 ). Application of $\mathrm{P}$ by $500 \mathrm{~mm} / \mathrm{yr}$ of TME irrigation would depend on the $\mathrm{P}$ concentration in the TME, as shown in Table 3.P leached will depend on the water-soluble $\mathrm{P}$, and the water flux, as shown in Eq. (3):

P leached $(\mathrm{kg} P / \text { ha } / y r)_{n}=$ Water soluble $P(m g / L)_{n} x$ Water flux $(\mathrm{mm}) / 100$

Water-soluble $P$ was calculated as a fraction of Olsen extractable P (McDowell and Condron 2004; Sánchez-Alcalá et al. 2014). Initial Olsen $P$ and the fraction of Olsen $P /$ Total $\mathrm{P}$ were those measured in the control lysimeters in the two soils. Fractions Olsen P/Total P and Soluble P/Olsen P were considered constant based on historical $\mathrm{P}$ unpublished data 
from Lincoln University and on McDowell and Condron (2004) and Sánchez-Alcalá et al. (2014).

The water flux was calculated as shown in Eq. (4):

$$
\begin{aligned}
\text { Water flux }(\mathrm{mm}) & =\operatorname{Irrigation}(500 \mathrm{~mm})+\operatorname{Rainfall}(\mathrm{mm}) \\
& - \text { Evapotranspiration }(\mathrm{mm})
\end{aligned}
$$

Evapotranspiration was calculated interpolating the lysimeter data for each type of plant cover (Table 4) for the assumed rainfall and irrigation values, and Rainfall is the average annual rainfall in Banks Peninsula, NZ, in the last 20 years (Macara 2016).

Plant P uptake was calculated separately for each type of plant cover, based on lysimeter data. The pasture production was considered constant over the 50 years, since the results showed that water is the most limiting factor for plant growth. It was assumed that biomass was not limited by nutrients. Biomass production was interpolated from lysimeter data for each type of plant cover based on water supply of $1469 \mathrm{~mm} / \mathrm{yr}$ (rain + TME irrigation).

\section{Results and discussion}

\section{Water balance and biomass}

Irrigation with TME increased the drainage of the lysimeters (Table 4). In the Fluvial Recent soils without TME application, drainage was $22 \%$ of the input water (rainfall only), while in the treatment with the medium irrigation rate ( $836 \mathrm{~mm} / \mathrm{yr})$, this percentage was 37\%. In the case of Fragic Pallic soil, drainage was $19 \%$ of rainfall in control lysimeters, compared with $31 \%$ in the TME applied at $836 \mathrm{~mm} / \mathrm{yr}$. Although some authors reported a decreased infiltration rate in the long term (Bedbabis et al. 2014; Sparling et al. 2006), in the experiment, all the lysimeters receiving TME, even at the highest application rate, drained throughout the experiment. There was no ponding or visible evidence that the soil structure had been degraded.

Irrigation with TME significantly increased the biomass production in all the treatments (Table 4). The ryegrass growth in the Fragic Pallic soil lysimeters was significantly higher than the fescue/brown top mixture in the lysimeters containing Fluvial Recent soil: a $121 \%$ increase compared with $65 \%$ increase with the same TME irrigation rate. This is likely due to differences in species composition as well as previous soil management. The Fragic Pallic soil had higher fertility than the Recent Fluvial soil (Table 1). Increased biomass or yield is a general benefit of irrigation with TME. Such increases have been reported in studies with barley (Mohammad Rusan et al. 2007), olive trees (Bedbabis et al. 2015), pasture (Barton et al. 2005) and lettuce (Urbano et al. 2017) and other crops.

Figure 1 shows the seasonality of the water balance, rainfall and pasture production. The biggest differences in evapotranspiration between treatments happened during the warmest months (December to April). The biggest difference in biomass production between treatments also happened during this period. This was remarkable in March and April 2016, when there was negligible plant growth in the control lysimeters (Fig. 1 and Supp. Material), indicating that irrigation was essential to maintain production. This is especially relevant for climate change scenarios, where the East Coast of New Zealand is forecasted to have drier summers, with rainfall less evenly distributed along the year (MfE 2018) and more need of alternative water sources.

Only $1 \%$ of the total drainage in lysimeters irrigated with $836 \mathrm{~mm} / \mathrm{yr}$ TME occurred between October and April in both soil types (see Supp. Material). This percentage increased to $7 \%$ in the case of $1672 \mathrm{~mm} / \mathrm{yr}$ application rate. This implies
Table 3 Parameters used to simulate the risk of $P$ accumulation in the topsoil with

\begin{tabular}{|c|c|c|}
\hline Parameter & Fluvial Recent soil & Fragic Pallic soil \\
\hline Effluent $\mathrm{P}$ concentration (mg/L) & 5,10 or 15 & 5,10 or 15 \\
\hline Effluent application rate (mm/yr) & 500 & 500 \\
\hline $\mathrm{P}$ application rate $(\mathrm{kg} / \mathrm{ha} / \mathrm{yr})$ & 25,50, or 75 & 25,50 or 75 \\
\hline Water flux $(\mathrm{mm})^{1}$ & 482 & 400 \\
\hline Initial soil $\mathrm{P}$ concentration $(\mathrm{mg} / \mathrm{kg})$ & 599 & 1046 \\
\hline Initial Olsen P (mg/kg) & 11 & 41 \\
\hline Initial water-soluble $\mathrm{P}\left(\mathrm{CaCl}_{2}\right)(\mathrm{mg} / \mathrm{L})^{2}$ & 0.048 & 0.18 \\
\hline Soil density $\left(\mathrm{t} / \mathrm{m}^{3}\right)$ & 1.4 & 1.4 \\
\hline Simulation depth (m) & 0.3 & 0.3 \\
\hline Biomass production $(\mathrm{t} / \mathrm{ha} / \mathrm{yr})^{3}$ & 5.4 & 6.8 \\
\hline
\end{tabular}
TME irrigation 
Table 4 General parameters for the length of the experiment (17.5 months)

\begin{tabular}{lllll}
\hline Treatment & $\begin{array}{l}\text { Total irrigation } \\
(\mathrm{mm})\end{array}$ & $\begin{array}{l}\text { Total drainage } \\
(\mathrm{mm})\end{array}$ & $\begin{array}{l}\text { Total evapotranspiration } \\
(\mathrm{mm})\end{array}$ & $\begin{array}{l}\text { Biomass } \\
\text { production } \\
\text { (t/ha equiv. })\end{array}$ \\
\hline
\end{tabular}

Fluvial Recent soil

Control $\quad 0$

$446 \mathrm{~mm} / \mathrm{yr} \quad 632$

$836 \mathrm{~mm} / \mathrm{yr} \quad 1185$

$1672 \mathrm{~mm} / \mathrm{yr} \quad 2370$

Fragic Pallic soil

Control 0

$836 \mathrm{~mm} / \mathrm{yr} \quad 1185$

$\begin{array}{ll}169 \pm 22^{\mathrm{a}} & 610 \\ 485 \pm 23^{\mathrm{b}} & 926 \\ 736 \pm 17^{\mathrm{c}} & 1228 \\ 1375 \pm 11^{\mathrm{d}} & 1774 \\ 148 \pm 2.0^{\mathrm{a}} & 631 \\ 609 \pm 32^{\mathrm{b}} & 1355\end{array}$

$5.4 \pm 1.0^{\mathrm{a}}$

$6.3 \pm 0.6^{\mathrm{ab}}$

$8.9 \pm 0.6^{b}$

$12.3 \pm 0.2^{\mathrm{c}}$

$6.0 \pm 0.3^{\mathrm{a}}$

$13.3 \pm 0.7^{\mathrm{b}}$

Total rainfall was $779 \mathrm{~mm}$. Mean \pm standard error $(n=3)$. For each soil type, values with the same letter are not significantly different $(P<0.05)$. The Fluvial Recent soil and Fragic Pallic soil were tested independently

that, if possible, irrigation rates can be optimized in each season to maximize pasture production and minimize leaching.

\section{Nutrient balances}

The average concentration of $\mathrm{NO}_{3}{ }^{-}$in the TME $(18 \mathrm{mg} / \mathrm{L})$ was almost twice the maximum value $(10 \mathrm{mg} / \mathrm{L})$ for unrestricted irrigation of TME onto agricultural land according to guidelines in several states from the USA and other countries such as Arabia Saudi (EPA 2004) or for disposal in rivers according to the European Union (EEC 1991). The total P in the TME $(11 \mathrm{mg} / \mathrm{L})$ was fivefold higher than the maximum concentration allowed for TME disposal in surface water in the European Union (1-2 mg/L, EEC, 1991), or some states in the USA ( $1 \mathrm{mg} / \mathrm{L}, \mathrm{EPA}, 2004)$, and twice the guideline value for unrestricted use on agricultural land (EPA, 2004). When discharged into water bodies, $\mathrm{N}$ and $\mathrm{P}$ can exacerbate algal blooms and reduce water quality (Leip et al. 2015). Reused in irrigation at the medium rate $(836 \mathrm{~mm} / \mathrm{yr})$, TME would supply $146 \mathrm{~kg} \mathrm{~N} / \mathrm{ha} / \mathrm{yr}$ and $120 \mathrm{~kg} / \mathrm{P} / \mathrm{ha} / \mathrm{yr}$, as well as other nutrients such as $\mathrm{S}, \mathrm{K}, \mathrm{Mg}$ and $\mathrm{Ca}$ (Supp. Material), which, at the price of the lowest cost fertilizer in NZ, the total fertilizing value of this effluent at an application rate of $500 \mathrm{~mm} / \mathrm{yr}$ is about US\$ $840 \mathrm{ha} / \mathrm{yr}$ (Table 5). Note that the total value of the nutrients is less than the sum of the individual elements because some fertilizers contain more than one element.

In contrast to the findings of other authors (Barton et al. 2005; Mohammad Rusan et al. 2007), TME irrigation did not affect pasture's $\mathrm{N}$ concentration (Table 6), although it significantly increased the total amount of $\mathrm{N}$ taken up, due to the increased pasture growth. On the contrary, P concentration increased in proportion to the TME irrigation rates (Table 6), as also reported by previously cited authors. This indicates that $\mathrm{N}$ was, at least partially, a limiting nutrient for both types of pasture, while in the case of $\mathrm{P}$, pasture presented a luxury uptake (McLaren and Cameron 1996). For TME irrigation rates up to $836 \mathrm{~mm} / \mathrm{yr}$, pasture extracted similar or more $\mathrm{N}$ than that supplied by TME. If the experiment had included a second growing season, a higher $\mathrm{N}$ uptake would have likely been demonstrated. Therefore, it would be the case that pasture could remove the $\mathrm{N}$ added with TME at rates above $1000 \mathrm{~mm} / \mathrm{yr}$. This is consistent with the findings of other studies investigating TME land application (Barton et al. 2005; Mohammad Rusan et al. 2007).

In the highest irrigation rate $(1672 \mathrm{~mm} / \mathrm{yr})$, the mass of $\mathrm{N}$ added was 1.4 times greater than that taken up by pasture. That was the only treatment that showed an accumulation of $\mathrm{N}$ in the soil, mainly as mineral nitrogen $\left(\mathrm{NH}_{4}{ }^{+}, \mathrm{NO}_{3}{ }^{-}\right)$. In this study, the accumulation of inorganic $\mathrm{N}$ had only a small effect on the soil total $\mathrm{N}$ because total $\mathrm{N}>>$ inorganic $\mathrm{N}$. However, other authors have reported significant increases in total $\mathrm{N}$ after 5-10 years of TME irrigation (Bedbabis et al. 2015; Mohammad Rusan et al. 2007). The total inorganic $\mathrm{N}$ leached from all treatments was $<2 \mathrm{~kg} / \mathrm{ha}$ equiv. This was negligible compared to the $>40 \mathrm{~kg} / \mathrm{N} / \mathrm{ha} / \mathrm{yr}$ that can be leached from a grazed pasture (Menneer et al. 2004). It was also lower than the $\mathrm{NO}_{3}{ }^{-}$leached $(4.5-22 \mathrm{~kg} \mathrm{~N} / \mathrm{ha} / \mathrm{yr})$ reported by Barton et al. (2005), following TME irrigation at a rate of $400 \mathrm{~kg} / \mathrm{N} / \mathrm{ha} / \mathrm{yr}$.

Even after P luxury uptake, TME irrigation added five to seven times more $\mathrm{P}$ than the removed by the pasture, and there was negligible $P$ leaching (Table 6). The accumulation of $\mathrm{P}$ in the soil, or topsoil, was not detectable because the extra $\mathrm{P}$ applied $(120 \mathrm{~kg} / \mathrm{ha})$ was 30 -fold lower than the $\mathrm{P}$ concentration in soil. Over several years, $\mathrm{P}$ is likely to accumulate in the topsoil. Significant increases in P after 5 to 10 years of TME irrigation was reported by Barton et al. (2005), Mohammad Rusan et al. (2007) and Qian and Mecham (2005). The potential accumulation of $P$ in the top soil calculated for a period of 50 years of TME irrigation is shown in Fig. 2. With a P concentration in the TME similar to the one of this experiment $(10 \mathrm{mg} / \mathrm{L})$, over a 50 -year period of the total $\mathrm{P}$ concentration in the top $30 \mathrm{~cm}$ would increase from 1046 to $1349 \mathrm{mg} / \mathrm{kg}$ in the Fragic Pallic soil and from 599 to $1006 \mathrm{mg} / \mathrm{kg}$ in the Fluvial Recent soil (Fig. 2). Even with this increase, the total concentration at 
Fig. 1 Evapotranspiration (rainfall + irrigation - leachate), rainfall and biomass production during the experiment. Bars represent the biomass produced in each sampling event. Lines represent the cumulative evapotranspiration and rainfall each month. (A) Results for Recent Fluvial soil lysimeters and (B) for Fragic Pallic soil lysimeters

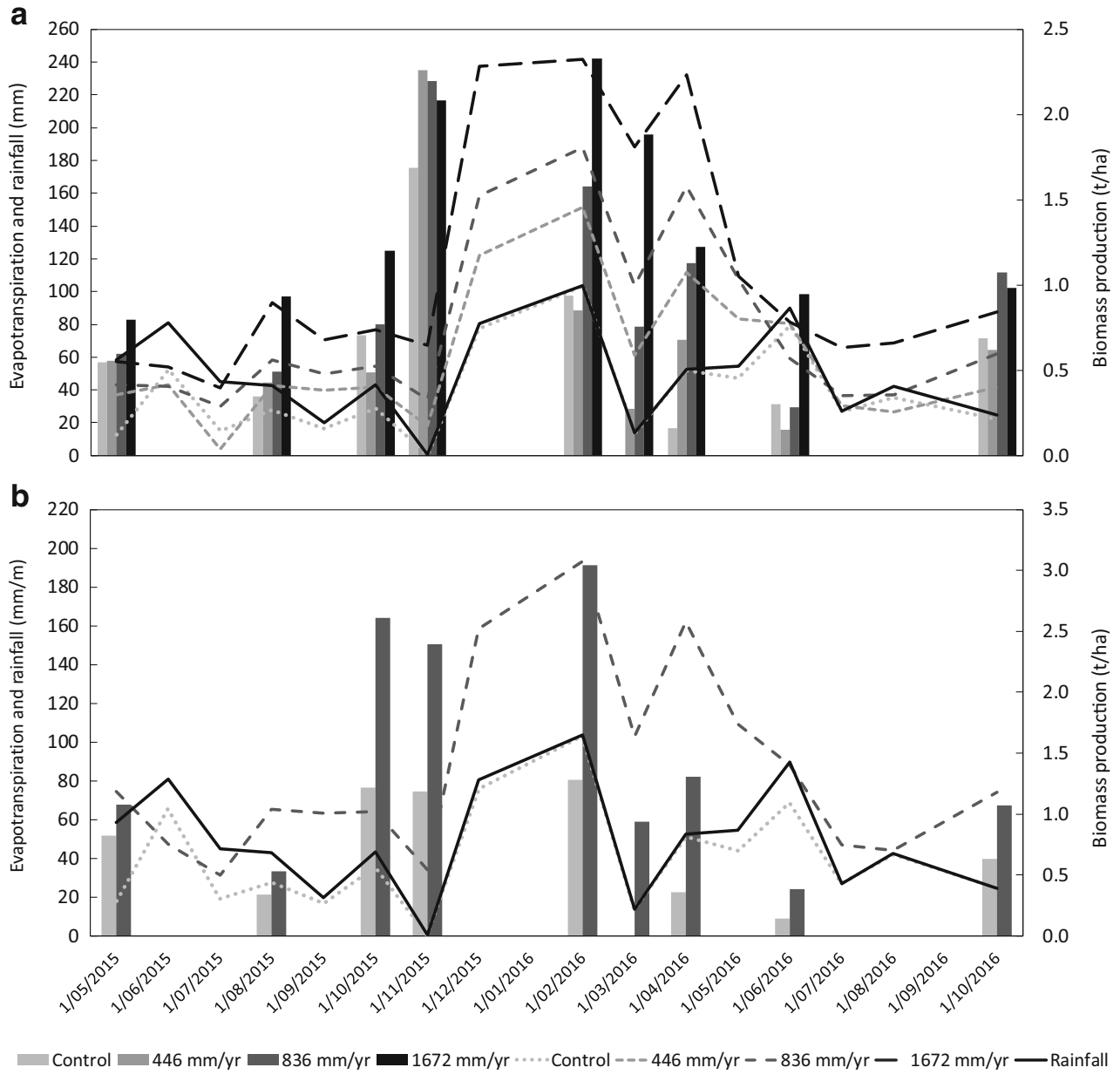

the end of the 50-year period would still be well within the range of $\mathrm{P}$ concentrations for $\mathrm{NZ}$ agricultural soils reported by McDowell and Condron (2004) and Reiser et al. (2014).

In the nominal case, the Olsen-extractable $\mathrm{P}$ in these soils is likely to increase from 41 to $53 \mathrm{mg} / \mathrm{kg}$ in the Fragic Pallic soil and increase from 11 to $18 \mathrm{mg} / \mathrm{kg}$ in the Fluvial Recent soil. The initial Olsen P concentration in the Fragic Pallic soil was within the range recommended by Dairy NZ $(35-40 \mathrm{mg} / \mathrm{kg})$ to maintain high productivity on sedimentary soils (DairyNZ

Table 5 Mass and value of plant macronutrients added through irrigating treated municipal effluent at a rate of $500 \mathrm{~mm}$ per year

\begin{tabular}{ccl}
\hline Element & Mass (kg/ha/yr) & $\begin{array}{l}\text { Value of element in } \\
\text { cheapest fertilizer (US\$/ha/yr) }\end{array}$ \\
\hline $\mathrm{N}$ & 95 & 72 \\
$\mathrm{P}$ & 55 & 135 \\
$\mathrm{~K}$ & 110 & 201 \\
$\mathrm{~S}$ & 125 & 262 \\
$\mathrm{Mg}$ & 95 & 175 \\
$\mathrm{Ca}$ & 295 & 249 \\
\hline
\end{tabular}

The value was calculated from the cheapest fertilizer (Ballance 2017)
2012). This is undoubtedly a result of the soil management under the previous land use, grazed pasture. In contrast, the Fluvial Recent soil, with an initial Olsen $\mathrm{P}$ concentration of $11 \mathrm{mg} / \mathrm{L}$ is consistent with non-productive but managed land, in this case a golf course. Even with an increase to $18 \mathrm{mg} / \mathrm{kg}$, the plant-available $\mathrm{P}$ would only be sufficient for low Prequiring crops such as golf course turf or for winter wheat (Tang et al. 2009). For pasture, Olsen $P$ values above $100 \mathrm{mg} / \mathrm{kg}$ are excessive, and values are considered "high" from 50 to $100 \mathrm{mg} / \mathrm{kg}$ (LandcareResearch 2018b).

Phosphorous from a TME-irrigated area could enter waterways via runoff, particularly if it is an easily erodible area. In that case, it could cause serious environmental issues (Tilman et al. 2001). However, the loss of P from a cut-and-carry pasture irrigated by TME will always be lower than the losses from a grazed pasture (TME irrigated or otherwise) because of the mechanical disturbance of soil by the animals' hooves (McDowell et al. 2003).

Although $\mathrm{S}, \mathrm{K}, \mathrm{Ca}$ and $\mathrm{Mg}$ are usually present at high concentrations in TME (Bedbabis et al. 2014; Qian and Mecham 2005), their behaviour in soil, plant or leachates is not as well studied as $\mathrm{N}$ and $\mathrm{P}$, probably because they are not usually linked to excessive eutrophication (Garnier et al. 
Table 6 Mass of $\mathrm{N}$ and $\mathrm{P}(\mathrm{kg} / \mathrm{ha}$ equiv., unless otherwise indicated) in the TME, pasture, soil and drainage water over the entire lysimeter experiment (17.5 months)

\begin{tabular}{|c|c|c|c|c|c|c|}
\hline Treatment & Irrigation & $\begin{array}{l}\text { Pasture } \\
\text { concentration }(N \\
\%, \mathrm{P} \mathrm{mg} / \mathrm{kg})\end{array}$ & $\begin{array}{l}\text { Pasture } \\
\text { uptake }\end{array}$ & $\begin{array}{l}\text { Soil total } \\
(0-60 \mathrm{~cm}) \\
(\mathrm{N} \mathrm{t} / \mathrm{ha})\end{array}$ & $\begin{array}{l}\text { Soil mineral N/ } \\
\text { Olsen P }(0- \\
60 \mathrm{~cm})\end{array}$ & Leached \\
\hline \multicolumn{7}{|l|}{ Nitrogen } \\
\hline \multicolumn{7}{|c|}{ Fluvial Recent soil } \\
\hline Control & 0 & $2.14 \pm 0.06^{\mathrm{ab}}$ & $115 \pm 21^{a}$ & $15.8 \pm 2.0^{\mathrm{a}}$ & $74 \pm 12^{a}$ & $\underset{\mathrm{a}}{0.32} \pm 0.03$ \\
\hline 446 mm/yr & 111 & $1.97 \pm 0.08^{b}$ & $\underset{\mathrm{ab}}{124} \pm 14$ & $13.4 \pm 2.0^{\mathrm{a}}$ & $63 \pm 6^{a}$ & $\underset{\mathrm{ab}}{0.72} \pm 0.08$ \\
\hline $836 \mathrm{~mm} / \mathrm{yr}$ & 207 & $2.18 \pm 0.01^{\mathrm{ab}}$ & $193 \pm 14^{b}$ & $13.1 \pm 1.0^{\mathrm{a}}$ & $95 \pm 6^{\mathrm{a}}$ & $\underset{\mathrm{b}}{1.09} \pm 0.03$ \\
\hline $1672 \mathrm{~mm} / \mathrm{yr}$ & 415 & $2.32 \pm 0.05^{a}$ & $\underset{c}{288} \pm 113$ & $15.0 \pm 1.3^{\mathrm{a}}$ & $161 \pm 17^{b}$ & $\underset{\mathrm{c}}{1.97} \pm 0.18$ \\
\hline \multicolumn{7}{|c|}{ Fragic Pallic soil } \\
\hline Control & 0 & $2.52 \pm 0.09^{\mathrm{a}}$ & $151 \pm 13^{a}$ & $19.7 \pm 1.2^{\mathrm{a}}$ & $78 \pm 16^{a}$ & $\underset{\mathrm{a}}{0.37} \pm 0.06$ \\
\hline 836 mm/yr & 207 & $2.36 \pm 0.07^{\mathrm{a}}$ & $314 \pm 11^{b}$ & $19.0 \pm 0.8^{\mathrm{a}}$ & $91 \pm 17^{\mathrm{a}}$ & $\underset{\mathrm{b}}{1.05} \pm 0.05$ \\
\hline \multicolumn{7}{|l|}{ Phosphorus } \\
\hline \multicolumn{7}{|c|}{ Fluvial Recent soil } \\
\hline Control & 0 & $2277 \pm 99^{a}$ & $13 \pm 2^{a}$ & $\underset{\mathrm{a}}{4140} \pm 464$ & $43 \pm 6.3^{a}$ & $<1$ \\
\hline $446 \mathrm{~mm} / \mathrm{yr}$ & 77 & $2722 \pm 91^{\mathrm{ab}}$ & $16 \pm 2^{a b}$ & $\underset{\mathrm{a}}{3500} \pm 641$ & $29 \pm 7.1^{a}$ & $<1$ \\
\hline 836 mm/yr & 144 & $2960 \pm 94^{b c}$ & $25 \pm 3^{b}$ & $\underset{\mathrm{a}}{3410} \pm 165$ & $29 \pm 0.8^{a}$ & $<1$ \\
\hline $1672 \mathrm{~mm} / \mathrm{yr}$ & 289 & $3382 \pm 113^{c}$ & $40 \pm 1^{\mathrm{c}}$ & $\underset{\mathrm{a}}{3720} \pm 415$ & $33 \pm 4.9^{\mathrm{a}}$ & $<1$ \\
\hline \multicolumn{7}{|c|}{ Fragic Pallic soil } \\
\hline Control & 0 & $3286 \pm 160^{a}$ & $20 \pm 2^{a}$ & $\underset{\mathrm{a}}{6020} \pm 485$ & $164 \pm 20^{a}$ & $<1$ \\
\hline 836 mm/yr & 144 & $3502 \pm 145^{a}$ & $45 \pm 2^{b}$ & $\underset{\mathrm{a}}{5670} \pm 100$ & $120 \pm 4.2^{\mathrm{a}}$ & $<1$ \\
\hline
\end{tabular}

Mean \pm standard error $(n=3)$. For each soil type, values with the same letter are not significantly different $P<0.05)$

2010; Leip et al. 2015). In this experiment, concentrations of $\mathrm{S}, \mathrm{K}, \mathrm{Ca}$ and $\mathrm{Mg}$ in pasture did not increase in response to the TME treatments. Nevertheless, the total nutrients extracted by the pasture in the treatments was higher due to the increased biomass (Tables S1 to S4). Uptake of S, Ca and Mg was between 8 and $17 \%$ of the added amount in the $836-\mathrm{mm} / \mathrm{yr}$ treatments and 34 and $70 \%$ of the K added in Recent Fluvial and Fragic Pallic soils, respectively. Only small amounts of these nutrients leached (up to $13 \%$ in the $836-\mathrm{mm} / \mathrm{yr}$ treatments), so most will accumulate in the soil. The accumulation in soil was insignificant because the soil concentrations were at least 100-fold greater than the amount being added and a difference might be only noticeable in the long term (Bedbabis et al. 2014; Bedbabis et al. 2015; Mohammad Rusan et al. 2007; Qian and Mecham 2005). The addition of $\mathrm{Mg}$ and $\mathrm{Ca}$ will offset the $\mathrm{Na}$ supply, and will help maintaining the soil structure (Abrol et al. 1988). The application of any element to a system at a rate greater than the rate that is removed is ultimately unsustainable (Mills et al. 2005).

\section{Sodium and trace elements}

The TME contained $95 \mathrm{mg} / \mathrm{L} \mathrm{Na}$, which is about $50 \%$ higher than the FAO guidelines for unrestricted use of effluent (FAO 2003). The SAR of the TME was 2.75 , which when assessed in combination with EC $(0.42 \mathrm{dS} / \mathrm{m})$ indicates that the TME has a "slight to moderate" use restriction, in terms of maintaining the soil structure and crop production (Ayers and Westcot 1985). Table 7 shows that TME irrigation added more Na to soil than the amount taken up by the pasture. At the medium application rate $(836 \mathrm{~mm} / \mathrm{yr})$, fescue/browntop and ryegrass uptake were 2 and $4 \%$, respectively, of the applied $\mathrm{Na}$. The $\mathrm{Na}$ concentration in pasture increased when increasing TME application rates (Table 7). The differences of plant Na between treatments were higher in the second half of the experiment (Fig. 3), above all for medium $(836 \mathrm{~mm} / \mathrm{yr})$ and high $(1672 \mathrm{~mm} / \mathrm{yr})$ rates. Zalacáin et al. (2019) also reported an increased $\mathrm{Na}$ concentration in leaves of plants irrigated with TME over a 15-year period. Elevated concentrations of $\mathrm{Na}$ in pasture increase its palatability to stock 

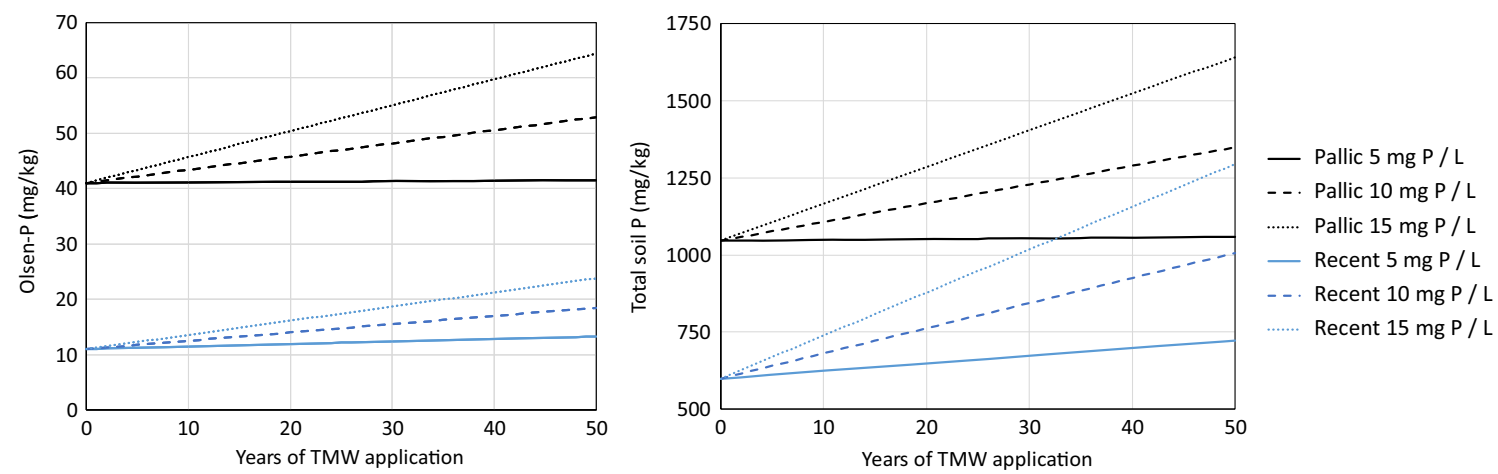

Fig. 2 Calculated $\mathrm{P}$ in the top $30 \mathrm{~cm}$ of the Fragic Pallic soil and Fluvial Recent Soil under irrigation with TME at $500 \mathrm{~mm} / \mathrm{yr}$ with a P concentration of 5, 10 or $15 \mathrm{mg} / \mathrm{L}$. The parameters used for the calculations are given in Table 3, and the equations are 1 to 4

(Chiy et al. 1998), and farmers occasionally apply $\mathrm{Na}$ to their pastures for this reason. Although most pasture species are not overly sensitive to $\mathrm{Na}$, the maximum concentration found in leaves $(0.6 \%)$ can be toxic for some sensitive plants (Ayers and Westcot 1985).

About $20 \%$ of the Na applied by medium TME application rate $(836 \mathrm{~mm} / \mathrm{yr})$ leached (Table 7). It also accumulated in the soil profile, mainly in the top horizons $0-15 \mathrm{~cm}$ and $15-30 \mathrm{~cm}$ (Fig. 4). This was also reported by Bedbabis et al. (2015), Qian and Mecham (2005) and Zalacáin et al. (2019). The control topsoil had ca. $300-\mathrm{mg} / \mathrm{kg} \mathrm{Na}$, whereas the topsoil under the low TME treatment $(446 \mathrm{~mm} / \mathrm{yr})$ contained significantly higher concentrations (ca. $400 \mathrm{mg} / \mathrm{kg}$ ). However, at the medium TME irrigation rate $(836 \mathrm{~mm} / \mathrm{yr}$, i.e., double the "low" rate), $\mathrm{Na}$ only increased to ca. $450 \mathrm{mg} / \mathrm{kg}$. Quadrupling the "low" TME irrigation rate increased the topsoil $\mathrm{Na}$ concentration to $460 \mathrm{mg} / \mathrm{kg}$. The results indicate that at soil concentrations $>$ ca. $400 \mathrm{mg} / \mathrm{kg}$, most additional $\mathrm{Na}$ was not retained by the soil and leached down through the soil profile (Table 7 and Fig. 4). Similar findings were also shown by Bedbabis et al. (2014), who demonstrated that soil Na increased 4.3 times after 5 years of $500 \mathrm{~mm} / \mathrm{TME} / \mathrm{yr}$ application and was only five times higher (compared with initial soil concentration) after 10 years of irrigation. SAR and ESP values in the topsoil follow the same pattern (see Supp. Material), with an increase between control soil and the 446- $\mathrm{mm} / \mathrm{yr}$ treatment (SAR from 0.87 to 1.48 , ESP from 5.2 to 9.4\%). Doubling irrigation rates did not double SAR and ESP in the soil (SAR 1.94 and 2.16 in 836- and 1672-mm/yr treatments in the Fluvial Recent soil, respectively, and ESP 12.5 and $13.4 \%$ in the same treatments). Even in the treatments with the highest rate of TME application, ESP remains lower than $15 \%$, a sodicity risk level of "none to slight" (Abrol et al. 1988). In spite of this Na accumulation, only the topsoil of the Fluvial Recent soil increased the EC with higher TME application rates (Fig. S5). EC in Fragic Pallic soil and pH in both soil types were not affected by TME application. It is possible that changes would happen in the long term, as usually reported by other authors (Bedbabis et al. 2015; Mohammad Rusan et al. 2007; Qian and Mecham 2005).

Although Na accumulation in the soil did not perturb drainage in this experiment, over the long term, a reduction in infiltration rates may occur (Assouline and Narkis 2011; Bedbabis et al. 2014). In that case, the soils may require periodic amendments with gypsum or dolomite to maintain structure (Abrol et al. 1988).

Boron and trace elements are occasionally a concern for the reuse of TME (Angin et al. 2005; Pedrero et al. 2010). On some occasions, crop yield has been decreased by the application of TME due to toxicity of one or various elements, as reviewed by Pedrero et al. (2010) and reported by Chatzakis et al. (2011). In this experiment, the concentrations of B, Al,
Table 7 Mass of $\mathrm{Na}(\mathrm{kg} / \mathrm{ha}$ equiv) in the treated municipal effluent, pasture, soil and drainage water during the experiment

\begin{tabular}{llllll}
\hline Treatment & $\begin{array}{c}\text { Irrigation Na } \\
\text { (kg/ha equiv. })\end{array}$ & $\begin{array}{l}\text { Average pasture } \\
\text { Na (mg/kg) }\end{array}$ & $\begin{array}{l}\text { Pasture Na } \\
(\mathrm{kg} / \text { ha equiv. })\end{array}$ & $\begin{array}{l}\text { Soil Na (0-60 cm) } \\
(\mathrm{kg} / \text { ha equiv. })\end{array}$ & $\begin{array}{l}\text { Na leached } \\
\text { (kg/ha equiv. })\end{array}$ \\
\hline Fluvial Recent soil & & & & \\
Control & 0 & $1741 \pm 270^{\mathrm{a}}$ & $10 \pm 3^{\mathrm{a}}$ & $2598 \pm 102^{\mathrm{a}}$ & $45 \pm 6^{\mathrm{a}}$ \\
$446 \mathrm{~mm} / \mathrm{yr}$ & 605 & $2028 \pm 205^{\mathrm{a}}$ & $13 \pm 3^{\mathrm{a}}$ & $3031 \pm 156^{\mathrm{ab}}$ & $159 \pm 18^{\mathrm{b}}$ \\
$836 \mathrm{~mm} / \mathrm{yr}$ & 1131 & $2836 \pm 138^{\mathrm{ab}}$ & $23 \pm 3^{\mathrm{a}}$ & $3195 \pm 149^{\mathrm{ab}}$ & $264 \pm 23^{\mathrm{b}}$ \\
$1672 \mathrm{~mm} / \mathrm{yr}$ & 2256 & $4002 \pm 499^{\mathrm{b}}$ & $45 \pm 6^{\mathrm{b}}$ & $3349 \pm 170^{\mathrm{b}}$ & $412 \pm 61^{\mathrm{c}}$ \\
Fragic Pallic soil & & & & \\
Control & 0 & $2121 \pm 85^{\mathrm{a}}$ & $13 \pm 1^{\mathrm{a}}$ & $2394 \pm 54^{\mathrm{a}}$ & $30 \pm 0^{\mathrm{a}}$ \\
$836 \mathrm{~mm} / \mathrm{yr}$ & 1131 & $3813 \pm 348^{\mathrm{b}}$ & $50 \pm 2^{\mathrm{b}}$ & $2919 \pm 89^{\mathrm{b}}$ & $232 \pm 32^{\mathrm{b}}$ \\
\hline
\end{tabular}

Mean \pm standard error. For each soil type, values with a different letter are significantly different $(P<0.05)$ 
Fig. 3 Sodium concentration in pasture $(\mathrm{mg} / \mathrm{kg})$ along the experiment. Bars represent standard error of the mean $(n=3)$. a Results from lysimeters of Fluvial Recent soil. b Results from lysimeters of Fragic Pallic soil. There was no biomass in control lysimeters in March 2016 (missing point)

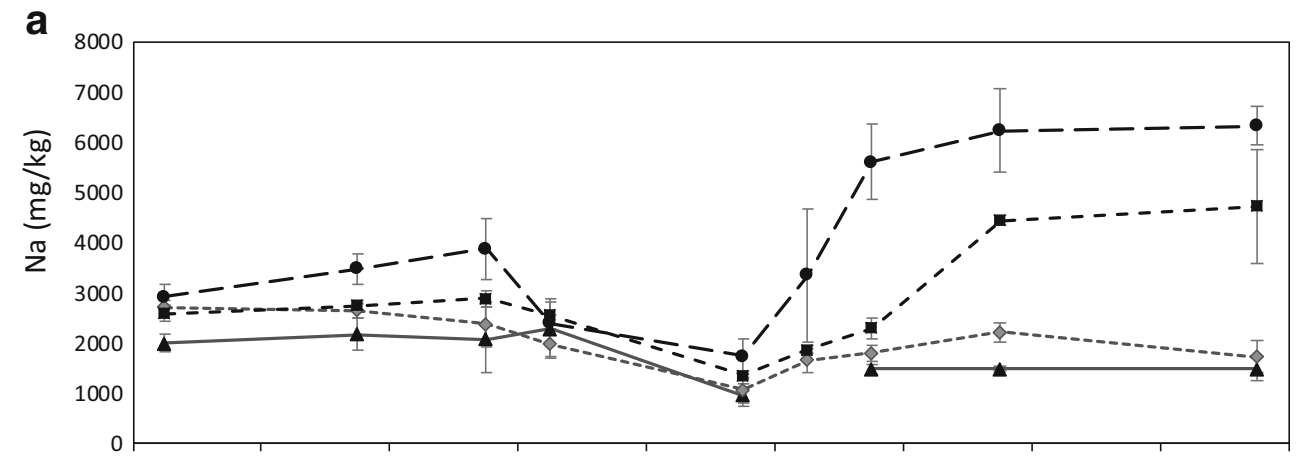

b

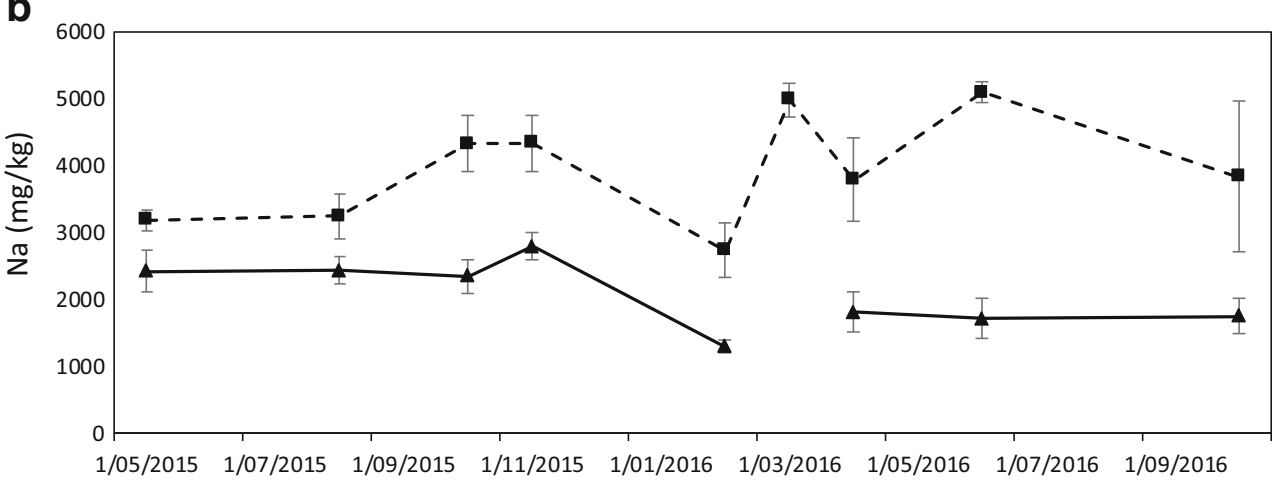

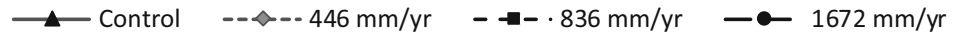

$\mathrm{Cd}, \mathrm{Cu}, \mathrm{Fe}, \mathrm{Mn}, \mathrm{As}$ and $\mathrm{Zn}$ in TME were below detection limits $(<0.001 \mathrm{mg} / \mathrm{Cd} / \mathrm{L})$ or much lower than the recommended limits (Table 1) for use in irrigation according to EPA (EPA 2004). Cd was not detected in the leachates or pasture (< $0.001 \mathrm{mg} / \mathrm{kg}$ ), and $\mathrm{B}, \mathrm{Al}, \mathrm{Cu}, \mathrm{Fe}, \mathrm{Mn}$ and $\mathrm{Zn}$ concentrations were not higher in TME irrigated treatments than in controls.

Although they were not an objective of this experiment, further consideration of emerging organic contaminants would increase the understanding of potential risks of TME irrigation into food chains or receiving environments (González García et al. 2019; Hurtado et al. 2016; MartínezPiernas et al. 2018).

Fig. 4 Soil Na concentration $(\mathrm{mg} / \mathrm{kg})$ as a function of depth at the end of lysimeter experiment for the Fluvial Recent soil (a) and Fragic Pallic soil (b). Bars represent the standard error of the mean $(n=3)$

\section{Conclusions and recommendations}

The TME from Duvauchelle treatment plant was suitable for pasture irrigation in both the Fluvial Recent soil and the Fragic Pallic soil. This experiment demonstrated that irrigation was fundamental for keeping the pasture production during the summer months, which recommends TME as an alternative water source in climate change scenarios with reduced water availability. TME irrigation would decrease the need of mineral fertilizers, and at a rate of $800 \mathrm{~mm} / \mathrm{yr}$, it could save about US\$ $840 \mathrm{ha} / \mathrm{yr}$ in fertilizing with $\mathrm{N}, \mathrm{P}, \mathrm{S}, \mathrm{K}, \mathrm{Ca}$ and $\mathrm{Mg}$. In case of a constant irrigation rate during the year, up to $800 \mathrm{~mm} / \mathrm{yr}$ would be an optimal

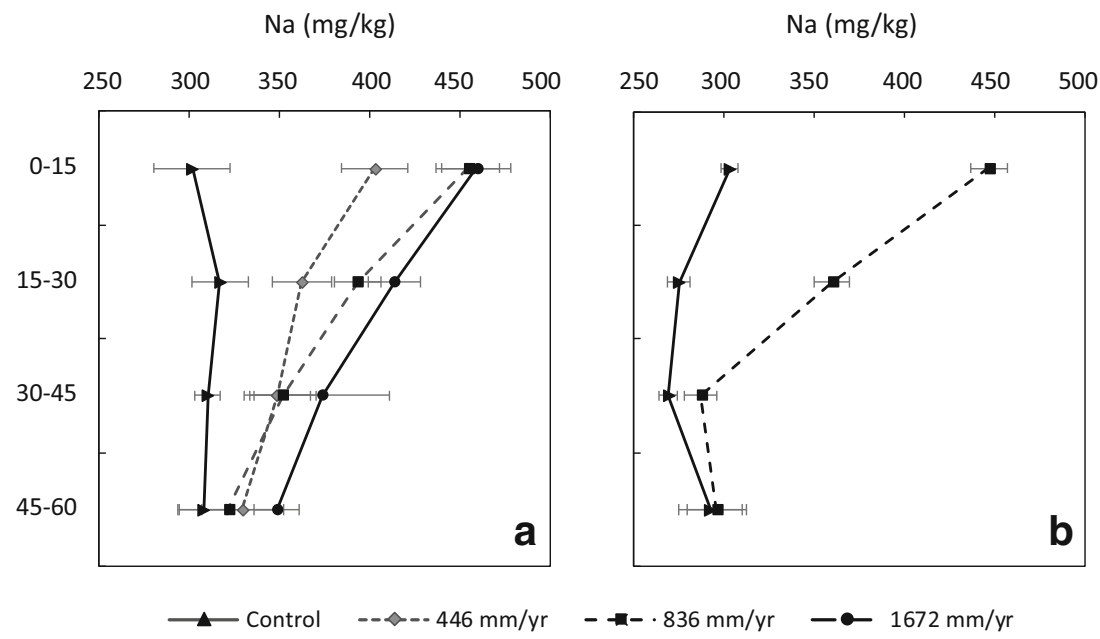


option, with an increase in pasture production, compared with non-irrigation, by $65 \%$, in the case of fescue/brown top over Fluvial Recent soil lysimeters, and by $121 \%$, in case of ryegrass over the Fragic Pallic soil lysimeters. At this application rate, the amount of $\mathrm{N}$ leached $(1 \mathrm{~kg} / \mathrm{N} / \mathrm{ha})$ was insignificant compared with grazed pastures $(\sim 40 \mathrm{~kg} / \mathrm{N} / \mathrm{ha})$. Adapting the irrigation rate in different seasons would allow to increase irrigation during summer up to $1500 \mathrm{~mm} / \mathrm{yr}$ without risk of nutrient leaching and to increase pasture production to an extra of $57 \%$.

It is unlikely that in the medium term ( $\sim 20$ years), $\mathrm{P}$ or $\mathrm{Na}$ accumulation in the soil will be a problem. In the worst case scenario of applying $75 \mathrm{~kg} / \mathrm{P} / \mathrm{ha} / \mathrm{yr}$, the total $\mathrm{P}$ concentration in the topsoil will rise to $57 \%$ over 50 years in the case of ryegrass over Fragic Pallic soil and $100 \%$ over 50 years in the case of fescue/browntop over Fluvial Recent soil. The final concentrations of the total $\mathrm{P}$ and Olsen P calculated for both scenarios were comparable with those on productive pastures in New Zealand. Although Na accumulated in the soil columns in all the TME treatments, the rate of accumulation was not proportional to the TME application rate, which indicates that $\mathrm{Na}$ was moving down through the soil profile and leaching. During the experiment, there was no evidence of ponding or decreased infiltration capacity. Na concentration in pasture increased with higher TME application rates. Highly productive cut and carry pasture, such as ryegrass for feed instead of fescue/browntop for turf, would be the best option for removing the N, P and Na supplied by TME. The amount of $\mathrm{P}, \mathrm{Ca}, \mathrm{S}, \mathrm{K}, \mathrm{Mg}$ and $\mathrm{Na}$ applied was higher than the uptake by pasture and the total leached in all the TME irrigated treatments. The application of any element to a system at a rate that is greater than the rate that is removed is ultimately unsustainable. The TME used in this experiment did not pose any risk related with trace elements. However, future work should investigate fluxes of contaminants associated with pharmaceuticals and/or personal care products in TME-irrigated soils.

Funding information Authors acknowledge the Christchurch City Council for funding this experiment and City Care for providing the treated municipal wastewater. This project was partially co-funded by the Centre for Integrated Biowaste Research, under the ESR Strategic Science Investment Funding from the Ministry of Business, Innovation and Employment, New Zealand (contract number C03X1701), New Zealand. MJGG held a scholarship from Fundacion Ramon Areces (Spain).

\section{Compliance with ethical standards}

Conflict of interest The authors declare that they have no conflict of interest.

Open Access This article is licensed under a Creative Commons Attribution 4.0 International License, which permits use, sharing, adaptation, distribution and reproduction in any medium or format, as long as you give appropriate credit to the original author(s) and the source, provide a link to the Creative Commons licence, and indicate if changes were made. The images or other third party material in this article are included in the article's Creative Commons licence, unless indicated otherwise in a credit line to the material. If material is not included in the article's Creative Commons licence and your intended use is not permitted by statutory regulation or exceeds the permitted use, you will need to obtain permission directly from the copyright holder. To view a copy of this licence, visit http://creativecommons.org/licenses/by/4.0/.

\section{References}

Abrol IP, Yadav JSP, Massoud FI (1988) Salt-affected soils and their management vol 39. FAO Soils Bulletin, Rome

Angin I, Yaganoglu AV, Turan M (2005) Effects of long-term wastewater irrigation on soil properties journal of sustainable agriculture. Ann Agric Sci 26:31-42. https://doi.org/10.1300/J064v26n03_05

Anon (1939) Soil Survey of Banks Peninsula. Akaroa Mail and Banks Peninsula Advertiser LXIII

Asgari K, Cornelis WM (2015) Heavy metal accumulation in soils and grains, and health risks associated with use of treated municipal wastewater in subsurface drip irrigation. Environ Monit Assess 187(7):410. https://doi.org/10.1007/s10661-015-4565-8

Assouline S, Narkis K (2011) Effects of long-term irrigation with treated wastewater on the hydraulic properties of a clayey soil. Water Resour Res 47(8). https://doi.org/10.1029/2011WR010498

Ayers RS, Westcot DW (1985) Water quality for agriculture vol 29 rev. 1. FAO irrigation and drainage paper. Food and agriculture Organization of the United Nations, Rome

Ballance (2017) Product price list. Accessed April 2017

Barton L et al (2005) Land application of domestic effluent onto four soil types. J Environ Qual 34:635-643. https://doi.org/10.2134/jeq2005.0635

Bedbabis S, Ben Rouina B, Boukhris M, Ferrara G (2014) Effect of irrigation with treated wastewater on soil chemical properties and infiltration rate. J Environ Manag 133:45-50. https://doi.org/10. 1016/j.jenvman.2013.11.007

Bedbabis S, Trigui D, Ben Ahmed C, Clodoveo ML, Camposeo S, Vivaldi GA, Ben Rouina B (2015) Long-terms effects of irrigation with treated municipal wastewater on soil, yield and olive oil quality. Agric Water Manag 160:14-21. https://doi.org/10.1016/j.agwat.2015.06.023

Blakemore LC, Searle PL, Daly BK (1987) Methods for chemical analysis of soils

Cameron KC, Di HJ, McLaren RG (1997) Is soil an appropriate dumping ground for our wastes? Soil Res 35:995-1036. https://doi.org/10. 1071/S96099

Cameron KC, Smith NP, McLay CDA, Fraser PM, McPherson RJ, Harrison DF, Harbottle P (1992) Lysimeters Without Edge Flow: An Improved Design and Sampling Procedure. Soil Sci Soc Am J 56:1625-1628. https://doi.org/10.2136/sssaj1992.03615995005600050048x

Chatzakis MK, Tzanakakis VA, Mara DD, Angelakis AN (2011) Irrigation of castor bean (Ricinus communis L.) and sunflower (Helianthus annus L.) plant species with municipal wastewater effluent: impacts on soil properties and seed yield. Water 3:1112

Chaudhry Q, Blom-Zandstra M, Gupta SK, Joner E (2005) Utilising the synergy between plants and rhizosphere microorganisms to enhance breakdown of organic pollutants in the environment (15 pp). Environ Sci Pollut Res 12:34-48. https://doi.org/10.1065/ espr2004.08.213

Chiy PC, Al-Tulihan A-1A, Hassan MH, CJC P (1998) Effects of sodium and potassium fertilisers on the composition of herbage and its acceptability to dairy cows. J Sci Food Agric 76:289-297. https://doi. org/10.1002/(SICI) 1097-0010(199802)76:2<289::AIDJSFA 959>3.0.CO;2-L

Clough TJ, Stevens RJ, Laughlin RJ, Sherlock RR, Cameron KC (2001) Transformations of inorganic-N in soil leachate under differing storage conditions. Soil Biol Biochem 33:1473-1480. https://doi.org/ 10.1016/S0038-0717(01)00056-6 
DairyNZ (2012) Phosphorus fertiliser

EEC (1991) Council Directive of 21 May 1991 concerning urban waste water treatment vol 91/271/EEC

EPA (2004) Guidelines for Water Reuse. U.S. Environmental Protection Agency U.S. Agency for International Development, Washington

FAO (2003) Users Manual for Irrigation with Treated Wastewater. FAO Regional Office for the Near East, Cairo. doi:http:/www.fao.org/ tempref/GI/Reserved/FTP_FaoRne/morelinks/Publications/ English/Usersmanual-en.pdf

Garnier J, Beusen A, Thieu V, Billen G, Bouwman L (2010) N:P:Si nutrient export ratios and ecological consequences in coastal seas evaluated by the ICEP approach. Global Biogeochem Cycles 24(4). https://doi.org/10.1029/2009gb003583

González García M, Fernández-López C, Polesel F, Trapp S (2019) Predicting the uptake of emerging organic contaminants in vegetables irrigated with treated wastewater - implications for food safety assessment. Environ Res 172:175-181. https://doi.org/10.1016/j. envres.2019.02.011

Hurtado C, Domínguez C, Pérez-Babace L, Cañameras N, Comas J, Bayona JM (2016) Estimate of uptake and translocation of emerging organic contaminants from irrigation water concentration in lettuce grown under controlled conditions. J Hazard Mater 305:139-148. https://doi.org/10.1016/j.jhazmat.2015.11.039

Kim N, Robinson BH (2015) Cadmium: a clandestine threat to food safety Food Quality \& Safety doi:https://www.foodqualityandsafety.com/ article/cadmium-a-clandestine-threat-to-food-safety/

Lal K, Minhas PS, Yadav RK (2015) Long-term impact of wastewater irrigation and nutrient rates II. Nutrient balance, nitrate leaching and soil properties under peri-urban cropping systems. Agric Water Manag 156:110-117. https://doi.org/10.1016/j.agwat.2015.04.001

LandcareResearch (2018a) New Zealand soil Classifiation. Manaaki Whenua - Landcare Research New Zealand Ltd. https://soilsmaps.landcareresearch.co.nz/\#maps

LandcareResearch (2018b) Olsen P Method https:// sindilandcareresearchconz/Content/HelpOlsenPhtml

Leip A et al (2015) Impacts of European livestock production: nitrogen, sulphur, phosphorus and greenhouse gas emissions, land-use, water eutrophication and biodiversity. Environ Res Lett 10:115004. https://doi.org/10.1088/1748-9326/10/11/115004

Macara GR (2016) The climate and weather of Canterbury vol number 68,2 nd edition edn.

Martínez-Piernas AB, Plaza-Bolaños P, García-Gómez E, FernándezIbáñez P, Agüera A (2018) Determination of organic microcontaminants in agricultural soils irrigated with reclaimed wastewater: target and suspect approaches. Analytica Chimica Acta 1030:115-124. https://doi.org/10.1016/j.aca.2018.05.049

McDowell RW, Condron LM (2004) Estimating phosphorus loss from New Zealand grassland soils. N Z J Agric Res 47:137-145. https:// doi.org/10.1080/00288233.2004.9513581

McDowell RW, Drewry JJ, Muirhead RW, Paton RJ (2003) Cattle treading and phosphorus and sediment loss in overland flow from grazed cropland. Soil Res 41:1521-1532. https://doi.org/10.1071/SR03042

McLaren RG, Cameron KC (1996) Soil Science. Sustainable production and environmental protection. Oxford Univeristy Press

Menneer JC, Ledgard SF, Gillingham AG (2004) Land use impacts on nitrogen and phosphorus loss and management options for intervention. Client report for Environment Bay of Plenty, Wellington

MfE (2018) Climate change projections for New Zealand: atmosphere projections based on simulations from the IPCC fifth assessment, 2nd edition edn. Ministry for the Environment, Wellington

MfE, MPI (2018) Essential freshwater: healthy water, fairly allocated. Ministry for the Environment and Ministry for Primary Industries, Wellington

Mills TM, Robinson BH, Sivakumaran S, Arnold B, Clothier BE (2005) Kim N current practice and future land-use: the sustainabillity of productive sector environments. In: Drew R (ed) The international symposium on harnessing the potential of horticulture in the AsianPacific region. Coolum, Canberra

Mohammad Rusan MJ, Hinnawi S, Rousan L (2007) Long term effect of wastewater irrigation of forage crops on soil and plant quality parameters. Desalination 215:143-152. https://doi.org/10.1016/j. desal.2006.10.032

Mojid MA, Wyseure GCL (2013) Implications of municipal wastewater irrigation on soil health from a study in Bangladesh. Soil Use Manag 29:384-396. https://doi.org/10.1111/sum.12056

Olsen SR, Cole CV, Watanabe FS, Dean LA (1954) Estimation of available phosphorous in soils by extraction with sodium bicarbonate

Pedrero F, Kalavrouziotis I, Alarcón JJ, Koukoulakis P, Asano T (2010) Use of treated municipal wastewater in irrigated agriculturereview of some practices in Spain and Greece. Agric Water Manag 97:1233-1241. https://doi.org/10.1016/j.agwat.2010.03.003

Prosser JA, Woods RR, Horswell J, Robinson BH (2016) The potential in-situ antimicrobial ability of Myrtaceae plant species on pathogens in soil. Soil Biol Biochem 96:1-3

Qian YL, Mecham B (2005) Long-term effects of recycled wastewater irrigation on soil chemical properties on golf course fairways. Agron Journal 97:717-721. https://doi.org/10.2134/agronj2004.0140

Rattan RK, Datta SP, Chhonkar PK, Suribabu K, Singh AK (2005) Longterm impact of irrigation with sewage effluents on heavy metal content in soils, crops and groundwater - a case study agriculture. Ecosyst Environ 109:310-322. https://doi.org/10.1016/j.agee.2005.02.025

Reiser R, Simmler M, Portmann D, Clucas L, Schulin R, Robinson B (2014) Cadmium concentrations in New Zealand pastures: relationships to soil and climate variables. J Environ Qual 43:917-925. https://doi.org/10.2134/jeq2013.09.0367

Sánchez-Alcalá I, del Campillo MC, Barrón V, Torrent J (2014) The Olsen P/solution P relationship as affected by soil properties. Soil Use Manag 30:454-462. https://doi.org/10.1111/sum.12141

Sonune A, Ghate R (2004) Developments in wastewater treatment methods. Desalination 167:55-63. https://doi.org/10.1016/j.desal.2004.06.113

Sparling GP et al (2006) Nutrient leaching and changes in soil characteristics of four contrasting soils irrigated with secondary-treated municipal wastewater for four years. Soil Res 44:107-116. https://doi. org/10.1071/SR05084

Tang X, Ma Y, Hao X, Li X, Li J, Huang S, Yang X (2009) Determining critical values of soil Olsen-P for maize and winter wheat from longterm experiments in China. Plant Soil 323:143-151. https://doi.org/ 10.1007/s11104-009-9919-y

Tanji KK (1997) Irrigation with marginal quality waters: issues. J Irrig Drain Eng 123:165-169. https://doi.org/10.1061/(ASCE)07339437(1997)123:3(165

Tilman D, Fargione J, Wolff B, D'Antonio C, Dobson A, Howarth R, Schindler D, Schlesinger WH, Simberloff D, Swackhamer D (2001) Forecasting agriculturally driven global environmental change. Science 292:281-284. https://doi.org/10.1126/science.1057544

Urbano VR, Mendonça TG, Bastos RG, Souza CF (2017) Effects of treated wastewater irrigation on soil properties and lettuce yield. Agric Water Manag 181:108-115. https://doi.org/10.1016/j.agwat.2016.12.001

Xu J, Wu L, Chang AC, Zhang Y (2010) Impact of long-term reclaimed wastewater irrigation on agricultural soils: A preliminary assessment. J Hazard Mater 183:780-786 doi:https://doi.org/10.1016/j. jhazmat.2010.07.094

Zalacáin D, Martínez-Pérez S, Bienes R, García-Díaz A, Sastre-Merlín A (2019) Salt accumulation in soils and plants under reclaimed water irrigation in urban parks of Madrid (Spain). Agric Water Manag 213: 468-476. https://doi.org/10.1016/j.agwat.2018.10.031

Publisher's note Springer Nature remains neutral with regard to jurisdictional claims in published maps and institutional affiliations. 